\title{
Spatio-Temporal Variation of Evapotranspiration and Its Sensitivity to Climatic Factors in Togo
}

\author{
BALAKA Manamboba Mitélama ${ }^{1 *}$, YOVO Koffi ${ }^{2}$
}

\author{
${ }^{1}$ University of Lomé-Togo / Faculty of Economics and Management (FASEG) \\ ${ }^{2}$ University of Lomé-Togo / Advanced School of Agronomy (ESA)
}

DOI: $10.36347 /$ sjebm.2021.v08i04.001

| Received: 26.02.2021 | Accepted: 29.03.2021 | Published: 07.04.2021

*Corresponding author: BALAKA Manamboba Mitélama

Abstract

Original Research Article

Climate change affects meteorological variables and the hydrological cycle with consequences for agricultural activity. To assess the impact of climate change on the hydrological cycle, this study analyzes the spatio-temporal variability of evapotranspiration in Togo and its sensitivity to meteorological variables that influence it at the monthly, annual and seasonal scales. The data analyzed are from ten (10) synoptic meteorological stations distributed over the country. The Mann-Kendall test, the median slope estimator of Sen (1968) and the Spearman rank correlation coefficient are used, allowing non-parametric statistical analysis. The results show a general upward trend in inter-season, intra and interyear evapotranspiration. The sensitivity analysis test shows that temperature (maximal and minimal) is the main variable influencing national, regional and seasonal variation in evapotranspiration. This is followed by relative humidity (maximal and minimal), precipitation and insolation. The results raise concerns for food security in Togo inasmuch as increases in evapotranspiration and in its main drivers (rainfall and temperature) coupled with decreases in relative humidity and insolation negatively affect agricultural production. These results can be useful for planning irrigation, water resource management and agricultural production, feasible adaptation strategies for strengthening observation systems required to reduce the vulnerability of local populations.

Keywords: Evapotranspiration, Trend, Correlation, Nonparametric approaches, Togo.

Copyright $($ C 2021 The Author(s): This is an open-access article distributed under the terms of the Creative Commons Attribution 4.0 International License (CC BY-NC 4.0) which permits unrestricted use, distribution, and reproduction in any medium for non-commercial use provided the original author and source are credited.

\section{INTRODUCTION}

Climate change, caused by anthropogenic activities, affects water resources and the different components of the hydrological cycle including evapotranspiration [1-4]. The latter is influenced by climate variation and directly or indirectly by other meteorological variables (precipitation, temperature, insolation, wind speed and relative humidity) and soil and plant characteristics [5, 6]. Evapotranspiration, the union of soil evaporation and plant transpiration, is the main indicator of climate change because of its relationship with other meteorological variables [5, 7]. Evapotranspiration is an important element of the hydrological cycle that reflects the maximum atmospheric demand for water to maintain water balance [8]. Its variations, in combination or not with precipitation, can contribute to changes in hydrological indices [9]. Spatio-temporal variations in potential evapotranspiration provide a clearer picture of the movement of the water cycle [10]. Understanding the mechanism of potential evapotranspiration at the global, regional and local scales is important to the fields of hydrology and agriculture $[11,12]$.
Evapotranspiration affects crop water requirements and water allocation for agriculture [13]. Its Variations also affect hydrological processes and crop yields $[14,15]$. It is an important component of the hydrological cycle and plays an important part in crop growth, water demand and irrigation management [6]. It is also important for climatology, plant growth estimation and agricultural irrigation management [16, 17].

Although global warming is widely confirmed, the trend in potential evapotranspiration is unclear and could increase or decrease depending on climatic conditions and regions [18]. Several research studies in different parts of the world have indicated that the variation in potential evapotranspiration has increased [5, 6, 19-24]. Increasing trends are detected in longterm evapotranspiration series in England [25, 26], the Arabian Peninsula [20], southern Spain [27], the western half of Iran [28], the Nile Basin [29], Burkina Faso [30], Israel [31] and India [16]. 
Other studies have revealed declining trends in evapotranspiration in recent decades across world regions [32-34]. Declining trends are found in Russia [35], the western and eastern United States [15, 35, 36], Israel [31], Australia [37], New Zélande [38], India [34, 39], Italy [40], the Tibetan plateau [41,42], China $[8,43,44]$. In addition, other research on the trend in potential evapotranspiration has found mixed trends. Indeed rising and falling trends were detected in the Canadian prairies from 1971 to 2000 [45], China from 1961 to 2008 [8], India from 1950 to 2005 (5), the Sahelian region of Tunisia [6], Benin [9].

These different results can be explained by the complex non-linear relationship between potential evapotranspiration and its determinants which are other meteorological variables [8]. There is no consensus on the causes of the variation in potential evapotranspiration. Indeed, most studies that have analyzed the sensitivity of evapotranspiration to other meteorological variables in different regions have linked it to global warming [9]. However, studies by $\mathrm{Xu}$ et al. [44] and Ohmura et al. Wild [46] indicate that the trend in potential evapotranspiration is not solely dependent on temperature. Espadafor et al. [27] in southern Spain linked the trend in potential evapotranspiration to air temperature, solar radiation and relative humidity. Goyal [47] related it, in the arid zone of Rajasthan in India, to surface temperature, solar radiation, wind speed and vapour pressure. Zhang et al. [48] found that the variation in reference evapotranspiration was related to variations in solar radiation and wind speed in China. Sonali et Kumar [5] in India found a high correlation between potential evapotranspiration and maximum temperatures at both monthly and seasonal scales. Yin et al. [8] attributed the trend in potential evapotranspiration to wind speed, sunshine duration and maximum temperature in China.

The effects of changes in evapotranspiration variation on agricultural crops make it crucial to examine its spatio-temporal variation in the context of climate change. This is useful for water resource planning and management as well as for agricultural production [6, 49]. This analysis also allows to propose feasible adaptation strategies [50]. Togo, like other West African countries, has been experiencing significant spatio-temporal variations in weather patterns since the late 1960s with consequences on agriculture, the main activity of the majority of the population [51, 52]. Consequently, since agricultural production in Togo is mainly rain-fed, inter- and intraannual variability in evapotranspiration affects the agricultural production system and requires further study. The detection and characterization of evapotranspiration trends is necessary to explain the impacts of climate change on ecosystems and agricultural production activities. Therefore, the objective of this study is to analyze the spatio-temporal variability of evapotranspiration and to measure its sensitivity to other meteorological variables. This is to provide farmers and decision-makers with useful information for decision-making on the one hand and to suggest adaptation strategies and agricultural practices that are feasible on the other hand.

\section{METHODS OF ANALYSIS AND DATA COLLECTION}

At first, an analysis of evapotranspiration spatio-temporal variability and trends is made. Then, the Spearman correlation is used to evaluate the correlation between evapotranspiration and other meteorological variables.

\subsection{Methods of analysis}

Analysis of the spatial-temporal dynamics of climate variables is based on a number of techniques that are generally classified into two categories: variability and trend analysis techniques.

\subsubsection{Variability analysis}

Analysis of variability involves the use of statistical parameters such as mean, standard deviation $(\sigma)$, skewness coefficient $\left(C_{s}\right)$, kurtosis coefficient $\left(C_{k}\right)$, coefficient of variation $\left(C_{v}\right)$.

\section{Fisher's asymmetry coefficient (skewness)}

It is determined as follows (53) :

$$
C_{S}=\frac{\sum_{i=0}^{n}\left(x_{i}-\bar{x}\right)^{3}}{n * \sigma^{3}}
$$

It can be positive or negative. $\mathrm{Si}-0.5 \leq C_{s}<0.5$; the series is fairly symmetrical. If $-1 \leq C_{S}<-0.5$ or $0.5 \leq$ $C_{s} \leq 1$; the series is moderately biased. If $C_{s}<-1$ or $C_{s}>1$; the series is highly skewed.

\section{Pearson Flattening Coefficient (kurtosis)}

It is defined as follows (53) :

$$
C_{k}=\frac{\sum_{i=0}^{n}\left(x_{i}-\bar{x}\right)^{4}}{n * \sigma^{4}}
$$

If $C_{k}=3$, the distribution is said to be mesokurtic or normal. If $C_{k}<3$, the distribution is said to be platykurtic or hypo normal (less flattened). If $C_{k}>3$, the distribution is said to be leptokurtic or hyper normal (more flattened).

\section{Coefficient of variation}

It is calculated as (50):

$$
C_{v}=\frac{\sigma}{\bar{x}} * 100
$$

With $C_{v}$ the coefficient of variation. According to Hare (54), $C_{v}$ is used to classify the degree of variability of climate events as lower $\left(C_{v}<20 \%\right)$, moderate $(20 \%$ $\left.<C_{v}<30 \%\right)$, high $\left(C_{v}>30 \%\right)$, very high $\left(C_{v}>40 \%\right)$ and extremely high $\left(C_{v}>70 \%\right)$. 


\section{Percentage change over time series}

It is calculated using the median slope of Theil and Sen, and evaluating the average over the period as follows $[53,55]$ :

Var en $\%=\frac{\text { median slope }\left(Q_{i}\right) * \text { length of period }(n)}{\text { mean }}$

\subsubsection{Trend analysis}

Different statistical testing methods are used to analyze trends in the fields of hydrology and hydrometeorology. In general, these methods are classified into two categories: parametric and nonparametric. Because of the low probability of the normal distribution in hydrological and climate time series data, non-parametric tests are mainly used [49, 50, 53]. The Mann-Kendall test and the rho test of Spearman are the most important and common [53]. In this study, the Mann-Kendall test and the slope estimation of Sen [56] are used.

\section{Mann-Kendall test}

This is a non-parametric test developed by Mann [57] for the identification of monotonic trends in environmental, climatic or hydrological data series and by Kendall [58] for the magnitude of the statistical distribution of the test. The MK test is used in this study to detect the presence of monotonic (increasing or decreasing) trends in meteorological variables and determine whether or not the trend is statistically significant. This choice is justified by the fact that outliers are likely to be present in the data set. The nonparametric test of MK is useful because its statistic is based on the signs (+ or -), rather than the values of the random variable. As a result, trends determined are less affected by outliers [59]. The Mann-Kendall test statistic is calculated on the basis of Mann [57], Kendall [58], El-Nesr [20], Chattopadhyay and Edwards [49] and Aawar et al. [53] using the following formula:

$$
S=\sum_{i=1}^{n-1} \sum_{j=i+1}^{n} \operatorname{sign}\left(x_{j}-x_{i}\right)
$$

The trend test is carried out on a time series $x_{i}$ ranked from $i=1,2, \ldots \mathrm{n}-1$ and $x_{j}$, ranked from $j=\mathrm{i}+$ $1,2, \ldots \mathrm{n}$. Each of the $x_{i}$ data points is taken as a reference point that is compared to the rest of the $x_{j}$ data points after $[5,50,53,57,58]$ :

$$
\operatorname{sign}\left(x_{j}-x_{i}\right)= \begin{cases}+1 & \text { if }\left(x_{j}-x_{i}\right)>0 \\ 0 & \text { if }\left(x_{j}-x_{i}\right)=0 \\ -1 & \text { if }\left(x_{j}-x_{i}\right)<0\end{cases}
$$

With $x_{i}$ and $x_{j}$ the annual/seasonal values of years/seasons $i$ and $j(j>i)$ respectively. The $(S)$ statistic is closely related to Kendal's $\tau$ given by Aawar et al. [53] and El-Nesr [20] respectively as follows:

$$
\begin{aligned}
\tau=\frac{s}{D}, \quad \text { with } D & =\left[\frac{1}{2} n(n-1)-\frac{1}{2} \sum_{p=1}^{q} t_{p}\left(t_{p}-1\right)\right]^{\frac{1}{2}}\left[\frac{1}{2} n(n-1)\right]^{\frac{1}{2}} \\
\tau & =\frac{s}{s_{\max }}, \quad \text { avec } \quad S_{\max }=\frac{1}{2} n(n-1)
\end{aligned}
$$

$S_{\max }$ is the maximum value of $S$. A positive (negative) $S$ or $\tau$ indicates an upward (downward) trend. It has been established that for a sample size greater $10(\mathrm{n} \geq 10)$, the $S$ statistic of the MK test is

$$
\sigma_{S}^{2}=\frac{1}{18}\left[n(n-1)(2 n+5)-\sum_{p=1}^{q} t_{p}\left(t_{p}-1\right)\left(2 t_{p}+5\right)\right]
$$

Where $n$ is the number of observations, $q$ is the number of linked groups in the data set (when certain data values appear more than once in the database, these groups of values are called linked groups) and $t_{p}$ is the number of data points in the pth linked group. In this equation, the second part supports linked data and sets the effects of the linked groups in the data set. Thus, the $(Z)$ statistic of Mann-Kendall, which is approximately normally distributed, is formalized as follows [5, 20, 49, 50, 53, 57, 58]:

$$
Z_{s}= \begin{cases}\frac{s-1}{\sigma_{S}}, & \text { if } S>0 \\ 0, & \text { if } S=0 \\ \frac{s+1}{\sigma_{S}}, & \text { if } S<0\end{cases}
$$

assumed to be normally distributed. Thus, the mean is $E[S]=0$ [58]. In this case, the variance of the $S$ statistic is defined as follows [5, 20, 49, 50, 53, 57, 58]:
Where $Z_{s}$ follows a normal distribution. A positive or negative $Z_{s}$ represent an upward and downward trend for the period, respectively.

\section{Sen's slope estimators}

Sen's [56] slope estimator is a non-parametric method complementary to the MK test for calculating the magnitude of trends. The non-parametric approach to the slope of Sen [56] shows the direction and magnitude of the trend in a time series. The linear $f(i)$ model can be described as follows [53]:

$$
f(i)=Q_{i}+B
$$


Where $Q_{i}$ is the slope and $B$ a constant. The magnitude of the trend is predicted by the slope estimator methods of $[56,60]$. Here, the slope $Q_{i}$ of all data pairs is calculated as [56]. To calculate the slope $Q_{i}$, it is necessary to calculate the slopes of all data pairs as follows [53]:

$$
Q_{i}=\frac{X_{j}-X_{k}}{j-k}, i=1,2, \ldots, \mathrm{N}, j>k
$$

Where $x_{j}$ and $x_{k}$ are considered as data values at the times $j$ and $k(j>k)$. The number of slopes belongs to the number of $X_{j}$ values, so if there are $\mathrm{n}_{j}$ values in a time series, then $N=\frac{n(n-1)}{2}$ corresponds to the $Q_{i}$ estimates of slope. The median of the $\mathrm{N}$ values of $Q_{i}$ indicate the slope estimator of [56]. The $\mathrm{N}$ values of $Q_{i}$ are sorted from the smallest to the largest and the estimator of Sen [56] given by Aawar et al. [53] is:

$$
Q_{\text {med }}=\left\{\begin{array}{lc}
Q_{\frac{N+1}{2}} & \text { if } N \text { is odd } \\
\frac{1}{2}\left(Q_{\frac{N}{2}}+Q_{\frac{N+2}{2}}\right) & \text { if } N \text { is even }
\end{array}\right.
$$

A positive value of $Q_{i}$ indicates an upward trend and a negative value of $Q_{i}$ a downward trend in the time series. The existence of positive serial correlation in a time series increases the probability that the MK test will detect a significant trend (serial correlation increases the probability of committing Type I error) [61]. Hamed and Rao [62] reported that the presence of serial correlation in a time series does not neither falsifies the asymptotic normality nor the mean of the $S$ statistic in the MK test, but the variance changes. Hence, correction factors are proposed to correct the variance of $S$ using only the uncorrelated samples. Yue et al. [63] found that "Pre-Whitening" changes the true slope present in the time series and suggested the TFPW-MK (Trend Free Pre-Whitening Mann Kendall) approach that takes into account the serial correlation effect in trend detection approaches. In addition, the presence of positive (negative) serial correlation leads to an increase (decrease) in the variance of the $S$ statistic of the MK test. Therefore, the variance correction approaches MMK-CF1 (Modified Mann Kendall) by Hamed and Rao [62] and MMK-CF2 (Modified Mann Kendall) by Yue and Wang (64) have been proposed. The modified variance of the $S$ statistic of the MK test is given by:

$$
\sigma_{\text {mods }}^{2}=C F * \sigma_{S}^{2}
$$

Where $\mathrm{CF}$ is the correction factor. The $\mathrm{CF}$ proposed by Hamed and Rao [62] and Yue and Wang [64] are designated by CF1 and CF2 respectively and defined as follows (5):

$$
\begin{aligned}
& C F_{1}=1+\frac{2}{n(n-1)(n-2)} \sum_{k=1}^{n-1}(n-k)(n-k-1) *(n-k-2) r_{k}^{R} \\
& C F_{2}=1+2 \sum_{k=1}^{n-1}\left(1-\frac{k}{n}\right) r_{k}
\end{aligned}
$$

Where $r_{k}$ and $r_{k}^{R}$ are the coefficients of the lag$\mathrm{k}$ serial correlation of the data and data ranks respectively, $n$ is the size of the series. In this study, the series of weather variables were examined for the presence of serial correlation in order to judge the need for "Pre-Whitening". The serial correlation coefficient $r$ is calculated as follows [39]:

$$
r=\frac{\frac{1}{n-1} \sum_{i=1}^{n-1}\left(x_{i}-\bar{x}\right)\left(x_{i+1}-\bar{x}\right)}{\frac{1}{n} \sum_{i=1}^{n}\left(x_{i}-\bar{x}\right)^{2}}
$$

No significant serial correlation is present if (49) :

$$
\frac{-1-1,645 \sqrt{n-2}}{n-1} \leq r \leq \frac{1+1,645 \sqrt{n-2}}{n-1}
$$

Thus, if $r$ lies between the two bounds, the MK test and the Sen's slope test are applied directly to the series of weather variables. Otherwise, the "PreWhitening" method is applied before estimation.

\subsubsection{Analysis of evapotranspiration sensitivity to other meteorological variables}

This study analyzes the correlation between evapotranspiration (ETr) and each of the other meteorological variables including precipitation $(\mathrm{Pr})$; maximal temperature (Tmax); minimal temperature (Tmin); maximal relative humidity (Hmax); minimal relative humidity (Hmin); insolation (I); and wind speed (W). This, in order to evaluate their links and the direction of influence throughout the year and the different seasons throughout Togo. Correlation is determined individually between Etr and the other meteorological variables at the annual scale, in rainy seasons and dry seasons. Spearman's non-parametric rank correlation is used to perform the correlation analysis. It is less sensitive to outliers than the Pearson Correlation and considers rank rather than magnitude. It measures monotonic relationship (linear or non-linear). It takes into account double values existing in time series [5]. 
BALAKA Manamboba Mitélama \& YOVO Koffi., Sch J Econ Bus Manag, Apr, 2021; 8(4): 98-109

In this study, several software and tools such as R, MAKESENS 1.0 Excel template and XLSTAT are used to analyze the meteorological data.

\subsection{Study area and data collection}

Togo is a French-speaking country in West Africa. It is located between $6^{\circ}$ and $11^{\circ} \mathrm{N}$ and $0^{\circ}$ and $1^{\circ} 40 \mathrm{E}$. Togo is subdivided into five (05) administrative regions (Maritime, Plateaux, Central, Kara and Savanes). The climatic and rainfall conditions in the five regions determine the cropping systems and cropping calendars. The latter are influenced by the rainy season regimes. The country is characterized by a bimodal rainfall regime in the South and a monomodal regime in the North. The country has two climatic zones: the Sudanian climate zone (kara and savannah regions) in the north and the Guinean climate zone (maritime and plateaux regions) in the south. The boundary between the two climatic zones is actually a transition zone that oscillates around $7^{\circ} \mathrm{N}$ [51].

The hydrographic system is made of three main basins: the Volta basin to the north drains over $26,700 \mathrm{~km}^{2}$ the main rivers (Oti, Kara, Mô) and represents $47.3 \%$ of the territory; the Mono basin drains over $21,300 \mathrm{~km}^{2}$ the main rivers (Mono, Anié, Amou), or $37.5 \%$ of the territory towards the south-east and the coastal basin (Lake Togo and rivers Zio and Haho) which represents $14.3 \%$ of the territory [65].

The data analyzed are provided by the meteorological department. The data on temperature, evapotranspiration, relative humidity, wind speed, sunshine and precipitation are taken from ten synoptic weather stations in Togo.

Table-1: Geographical details of synoptic weather stations in Togo

\begin{tabular}{|l|l|c|c|c|}
\hline Regions & Stations & Longitude & Latitude & Altitude \\
\hline \multirow{3}{*}{ Maritime } & Lomé & $01^{\circ} 15^{\prime}$ & $06^{\circ} 10^{\prime}$ & 19,6 \\
\cline { 2 - 5 } & Tabligbo & $01^{\circ} 30^{\prime}$ & $06^{\circ} 35^{\prime} 0$ & 44 \\
\hline \multirow{2}{*}{ Plateaux } & Kouma-Konda & $00^{\circ} 35^{\prime}$ & $06^{\circ} 57^{\prime}$ & 638 \\
\cline { 2 - 5 } & Atakpamé & $01^{\circ} 07^{\prime}$ & $07^{\circ} 35^{\prime}$ & 399,66 \\
\hline \multirow{2}{*}{ Kentrale } & Sotouboua & $00^{\circ} 976^{\prime}$ & $8^{\circ} 562^{\prime}$ & 384 \\
\cline { 2 - 5 } & Sokodé & $01^{\circ} 09^{\prime} 10^{\prime}{ }^{\circ}$ & $08^{\circ} 59^{\prime} 50^{\prime}{ }^{\prime}$ & 386,48 \\
\hline \multirow{2}{*}{ Kavanes } & Kara & $01^{\circ} 10^{\prime}$ & $09^{\circ} 33^{\prime}$ & 341,73 \\
\cline { 2 - 5 } & Niamtougou & $01^{\circ} 06^{\prime}$ & $09^{\circ} 46^{\prime}$ & 461,73 \\
\cline { 2 - 5 } & Mango & $00^{\circ} 22^{\prime}$ & $10^{\circ} 22^{\prime}$ & 144,7 \\
\cline { 2 - 5 } & Dapaong & $00^{\circ} 15^{\prime}$ & $10^{\circ} 52^{\prime}$ & 329,01 \\
\hline
\end{tabular}

Source: authors

\section{RESULTS AND DISCUSSION}

Primary statistical parameters such as mean, standard deviation $(\sigma)$, skewness coefficient $\left(C_{s}\right)$, flattening coefficient $\left(C_{k}\right)$, coefficient of variation $\left(C_{v}\right)$ and percentage change in time series are calculated using equations 1, 2, 3 and 4 at ten (10) synoptic meteorological stations in Togo. The results are presented in Table 2. Then, the normalized (Z) statistic of the Mann-Kendall test and the median slope estimator of Sen [56] are calculated using equations 5 to 17 for all meteorological variables. The results are presented in Table 3. The results of the analysis of evapotranspiration sensitivity to other weather variables are presented in Tables 4 and 5.

\subsection{Evapotranspiration dynamics analysis}

The results of the primary statistical parameters of evapotranspiration are compiled in Table 2. Annual and rainy season evapotranspiration varies from a minimum of $1440.00 \mathrm{~mm}$ (Lomé) and 819.80 $\mathrm{mm}$ (Dapaong) respectively to a maximum of 2138.70 $\mathrm{mm}$ (Mango) and $1649.36 \mathrm{~mm}$ (Atakpamé) respectively. In the dry seasons, the minimum is 120.70 $\mathrm{mm}$ and the maximum is $153.40 \mathrm{~mm}$ in Kouma-Konda. A Slight variation in evapotranspiration is recorded at all stations. Annual and rainy season evapotranspiration is moderately biased at most stations. In dry seasons, it is fairly symmetrical at most stations. In addition, annual and dry season evapotranspiration is less flattened at most stations. In the wet season, it is more flattened at most stations. 
BALAKA Manamboba Mitélama \& YOVO Koffi., Sch J Econ Bus Manag, Apr, 2021; 8(4): 98-109

Table-2: Evapotranspiration primary statistical parameters values (mm)

\begin{tabular}{|c|c|c|c|c|c|c|c|c|c|c|}
\hline Stations & Period & Min & Max & Mean & SD & $\mathrm{Cv}$ & Cs & $\mathbf{C k}$ & $\%$ chan, & $\mathbf{n}$ \\
\hline \multirow[t]{2}{*}{ Lomé } & Year & 1440.00 & 1689.60 & 1544.99 & 54.23 & 0.04 & 0.85 & 3.71 & 0.00 & \multirow[t]{2}{*}{46} \\
\hline & $\mathbf{R S}$ & 972.70 & 1128.20 & 1039.89 & 38.05 & 0.04 & 0.53 & 3.10 & 0.00 & \\
\hline \multirow[t]{2}{*}{ Tabligbo } & Year & 1761.45 & 1905.34 & 1836.34 & 35.05 & 0.02 & -0.29 & 2.29 & 0.02 & \multirow[t]{2}{*}{46} \\
\hline & $\mathbf{R S}$ & 1180.69 & 1275.44 & 1225.17 & 25.49 & 0.02 & 0.06 & 2.26 & 0.03 & \\
\hline \multirow[t]{2}{*}{ Kouma-Konda } & Year & 1451.20 & 1719.20 & 1549.57 & 68.11 & 0.04 & 0.82 & 2.90 & -0.01 & \multirow[t]{2}{*}{35} \\
\hline & $\mathbf{R S}$ & 1327.00 & 1570.00 & 1413.35 & 60.54 & 0.04 & 0.87 & 3.09 & 0.00 & \\
\hline \multirow[t]{2}{*}{ Atakpamé } & Year & 1676.32 & 1803.39 & 1754.58 & 30.69 & 0.02 & -0.62 & 2.70 & 0.03 & \multirow[t]{2}{*}{46} \\
\hline & $\mathbf{R S}$ & 1535.14 & 1649.37 & 1609.02 & 29.65 & 0.02 & -0.71 & 2.70 & 0.03 & \\
\hline \multirow[t]{2}{*}{ Sokodé } & Year & 1838.70 & 1989.70 & 1912.12 & 38.86 & 0.02 & 0.50 & 2.34 & 0.02 & \multirow[t]{2}{*}{46} \\
\hline & $\mathbf{R S}$ & 1006.40 & 1115.50 & 1066.14 & 25.68 & 0.02 & 0.18 & 2.66 & 0.02 & \\
\hline \multirow[t]{2}{*}{ Kara } & Year & 1831.00 & 2070.00 & 1987.08 & 46.25 & 0.02 & -1.21 & 4.94 & 0.03 & \multirow[t]{2}{*}{37} \\
\hline & $\mathbf{R S}$ & 1048.60 & 1157.60 & 1114.25 & 26.57 & 0.02 & -0.47 & 2.78 & 0.01 & \\
\hline \multirow[t]{2}{*}{ Niamtougou } & Year & 1789.17 & 1975.22 & 1868.13 & 42.13 & 0.02 & 0.11 & 2.58 & 0.03 & \multirow[t]{2}{*}{36} \\
\hline & $\mathbf{R S}$ & 995.73 & 1130.39 & 1046.50 & 29.78 & 0.03 & 0.29 & 3.02 & 0.02 & \\
\hline \multirow[t]{2}{*}{ Mango } & Year & 1933.40 & 2138.70 & 2039.72 & 43.83 & 0.02 & -0.44 & 3.20 & 0.02 & \multirow[t]{2}{*}{36} \\
\hline & $\mathbf{R S}$ & 888.50 & 997.70 & 961.32 & 25.53 & 0.03 & -0.97 & 3.67 & -0.01 & \\
\hline \multirow[t]{2}{*}{ Dapaong } & Year & 1770.80 & 2096.90 & 1884.23 & 83.99 & 0.05 & 0.70 & 2.96 & -0.05 & \multirow[t]{2}{*}{46} \\
\hline & $\mathbf{R S}$ & 819.80 & 1039.80 & 901.96 & 49.27 & 0.06 & 0.72 & 3.35 & -0.11 & \\
\hline
\end{tabular}

An : annual, SP : rainy season, Min : minimum, Max : maximum, Cv : coefficient of variance, Cs : coefficient of skewness, $\mathrm{Ck}$ : flattening coefficient, $\%$ chan. : percentage of change over time series, $\mathrm{n}:$ number of observations

Source: Authors

The results of the Mann-Kendall's and Sen's [56] tests, in Table 3, indicate a general upward trend in evapotranspiration. The maximum rates of change in values of annual and rainy season evapotranspiration are $-1.86 \%$ and $-2.18 \%$ (Dapaong) respectively. Indeed, an annual (Tabligbo, Atakpamé, Sokodé, Kara and Niamtougou), rainy seasons (Tabligbo, Atakpamé, Sokodé) and dry season (Tabligbo, Sokodé Kara, Niamtougou and Mango) significant upward trend is detected. On the other hand, a significant downward trend (annual and rainy season) is recorded in Dapaong.

There is also a general upward intra-annual trend in evapotranspiration. Indeed, significant upward trend is recorded in Tabligbo (February, July, October, November and December), Kouma-Konda (February and March), Atakpamé (March, April, September to December), Sokodé (January, March, June and December), Kara (January to March, June and November), Niamtougou (January to April, June, July, October and December). On the other hand, at Dapaong, a significant downward trend is detected from January to November.
The general upward trend in evapotranspiration obtained in this study is similar to the results obtained by Chaouche et al. [19] in the Pyrénées-Orientales and Aude in France, El-Nesr [20] in the Arabian Peninsula, Ibrahim [30] in Burkina Faso, Onyutha [29] in the Nile Basin, Jhajharia et al. [16] and Sonali et Kumar [5] in India.

This study shows that in addition to the general upward trend in evapotranspiration, spatial and temporal heterogeneities exist over the country as found by Mansour et al. [6] in Tunisia, Obada et al. [9] in Benin. This spatio-temporal variability of evapotranspiration is explained by its complex relationship with other meteorological variables such as temperature, relative humidity, insolation and wind speed [8]. Thus, the general upward trend in evapotranspiration observed in this study is explained by the general upward trend in maximal and minimal temperature as found by Obada et al. [9]. Increased evapotranspiration reduces the availability of water resources with consequences for agricultural production. 
BALAKA Manamboba Mitélama \& YOVO Koffi., Sch J Econ Bus Manag, Apr, 2021; 8(4): 98-109

Table-3: Mann-kendall and Sen tests applied to evapotranspiration (mm)

\begin{tabular}{|c|c|c|c|c|c|c|c|c|c|c|c|}
\hline Stations & \multicolumn{2}{|c|}{ Lomé } & \multicolumn{2}{|c|}{ Tabligbo } & \multicolumn{2}{|c|}{ Kouma-Konda } & \multicolumn{3}{|c|}{ Atakpamé } & \multicolumn{2}{|c|}{ Sokodé } \\
\hline $\begin{array}{c}\text { Statistic } \\
\text { S }\end{array}$ & $\begin{array}{c}\text { MK } \\
(\mathbf{Z})\end{array}$ & Qi & $\begin{array}{c}\text { MK } \\
(\mathbf{Z})\end{array}$ & Qi & MK (Z) & Qi & MK (Z) & Qi & MF & (Z) & Qi \\
\hline Jan & 0.98 & 0.1 & 1.31 & 0.11 & -0.3 & -0.06 & 0.81 & 0.04 & & & $0.12^{+}$ \\
\hline Feb & 0.01 & 0.00 & $1.76^{+}$ & $0.14^{+}$ & $-1.93^{+}$ & $-0.33^{+}$ & 1.36 & 0.07 & & & 0.09 \\
\hline Mar & -1.05 & -0.06 & 1.51 & 0.12 & $-2.39 *$ & $-0.27 *$ & $2.16 *$ & $0.13 *$ & 3.2 & $* *$ & $0.21 * *$ \\
\hline Apr & 0.07 & 0.01 & 1.48 & 0.08 & -1.39 & -0.14 & $2.03 *$ & $0.14 *$ & & & 0.04 \\
\hline May & 0.24 & 0.02 & 1.1 & 0.07 & -0.59 & -0.05 & 1.34 & 0.08 & & & 0.08 \\
\hline Jun & -1.07 & -0.06 & 1.18 & 0.07 & -0.71 & -0.07 & 1.16 & 0.08 & & & $0.09^{+}$ \\
\hline Jul & 0.15 & 0.01 & $2.88 * *$ & $0.17 * *$ & 0.21 & 0.01 & 1.59 & 0.12 & & & 0.08 \\
\hline Aug & -0.6 & -0.04 & 0.36 & 0.03 & -1.07 & -0.1 & 0.74 & 0.04 & & & 0.02 \\
\hline Sep & -0.01 & 0.00 & 1.31 & 0.06 & 0.00 & 1.99 & $2.84 *$ & $0.14 *$ & & & 0.06 \\
\hline Oct & 0.44 & 0.03 & $3.39 * * *$ & $0.14 * * *$ & -0.36 & -0.04 & $2.10 * *$ & $0.10 * *$ & & & 0.09 \\
\hline Nov & 0.01 & 0.00 & $1.89^{+}$ & $0.11^{+}$ & -0.03 & -0.01 & $1.87^{+}$ & $0.09^{+}$ & & & 0.11 \\
\hline Dec & 0.62 & 0.05 & $3.45 * * *$ & $0.20 * * *$ & 0.47 & 0.06 & $4.16 * * *$ & $0.22 * * *$ & & $* *$ & $0.17 * *$ \\
\hline Year & 0.3 & 0.1 & $2.83 * *$ & $0.94 * *$ & -0.3 & -0.24 & $2.89 * *$ & $0.96 * *$ & & & $0.75^{+}$ \\
\hline $\mathrm{RS}$ & 0.07 & 0.03 & $2.67 * *$ & $0.74 * *$ & -0.18 & -0.19 & $2.79 * *$ & $0.88 * *$ & & & 0.41 \\
\hline DS & 0.11 & 0.03 & $2.98 * *$ & $0.31 * *$ & -0.3 & -0.06 & 0.81 & 0.04 & & $* *$ & $0.62 * *$ \\
\hline Stations & \multicolumn{3}{|c|}{ Kara } & \multicolumn{2}{|c|}{ Niamtougou } & & \multicolumn{2}{|c|}{ Mango } & \multicolumn{3}{|c|}{ Dapaong } \\
\hline $\begin{array}{c}\text { Statistic } \\
\text { S }\end{array}$ & MK (Z) & & Qi & MK (Z) & Qi & & MK (Z) & Qi & MK (Z) & & Qi \\
\hline Jan & $2.63 * *$ & & $0.22 * *$ & $2.44 *$ & $0.20 *$ & & 1.5 & 0.18 & $-2.44 *$ & & $-0.23 *$ \\
\hline Feb & $1.66^{+}$ & & $0.14^{+}$ & $1.87^{+}$ & $0.15^{+}$ & & 0.8 & 0.08 & $-3.30 * * *$ & & $0.27 * * *$ \\
\hline Mar & $1.73^{+}$ & & $0.18^{+}$ & $3.75 * * *$ & $0.35 * * *$ & & $1.93^{+}$ & $0.20^{+}$ & $-2.14 *$ & & $-0.17 *$ \\
\hline Apr & -0.01 & & -0.01 & $1.73^{+}$ & $0.20^{+}$ & & 0.01 & 0.00 & $-2.96 * *$ & & $0.30 * *$ \\
\hline May & 0.6 & & 0.1 & 3.12 & 0.03 & & -0.78 & -0.11 & $-2.16 *$ & & $-0.22 *$ \\
\hline Jun & $1.67^{+}$ & & $0.14^{+}$ & $2.38 *$ & 0.19* & & 0.8 & 0.09 & $-3.26 * *$ & & $0.27 * *$ \\
\hline Jul & 1.62 & & 0.09 & $2.52 *$ & 0.19* & & 0.42 & 0.05 & $-4.74 * * *$ & & $0.49 * * *$ \\
\hline Aug & -0.9 & & -0.08 & 0.83 & 0.06 & & -1.02 & -0.1 & $-5.31 * * *$ & & $0.45 * * *$ \\
\hline Sep & -0.59 & & -0.07 & 1.13 & 0.08 & & -1.48 & -0.13 & $-4.25 * * *$ & & $0.30 * * *$ \\
\hline Oct & -0.1 & & -0.02 & $1.89^{+}$ & $0.19^{+}$ & & -0.78 & -0.08 & $-4.83 * * *$ & & $0.40 * * *$ \\
\hline Nov & $1.88^{+}$ & & $0.22^{+}$ & 1.02 & 0.12 & & 1.36 & 0.14 & $-2.42 *$ & & $-0.18 *$ \\
\hline Dec & 3.2 & & 0.3 & $3.95 * * *$ & $0.34 * * *$ & & $3.10 * *$ & $2.70 * *$ & -0.81 & & -0.05 \\
\hline Year & $2.50 *$ & & $1.40 *$ & 1.99* & $1.43 *$ & & 1.46 & 1.07 & $-3.37 * * *$ & & $1.86 * * *$ \\
\hline $\mathrm{RS}$ & 0.54 & & 0.29 & 7.67 & 0.45 & & -0.26 & -0.14 & $-5.25 * * *$ & & $2.18 * * *$ \\
\hline DS & $3.60 * * * *$ & & $1.10 * * *$ & $4.54 * * *$ & $1.60 * * *$ & & $2.98 * *$ & $1.15 * *$ & -1.59 & & -0.32 \\
\hline
\end{tabular}

RS: rainfall season, DR: dry season, Z: normalized statistic of the Mann-Kendall test, Qi: the median slope of Sen, +, *, ** and ***. statistically significant at $10 \%, 5 \%, 1 \%$ and $0.1 \%$ respectively.

Source: Authors

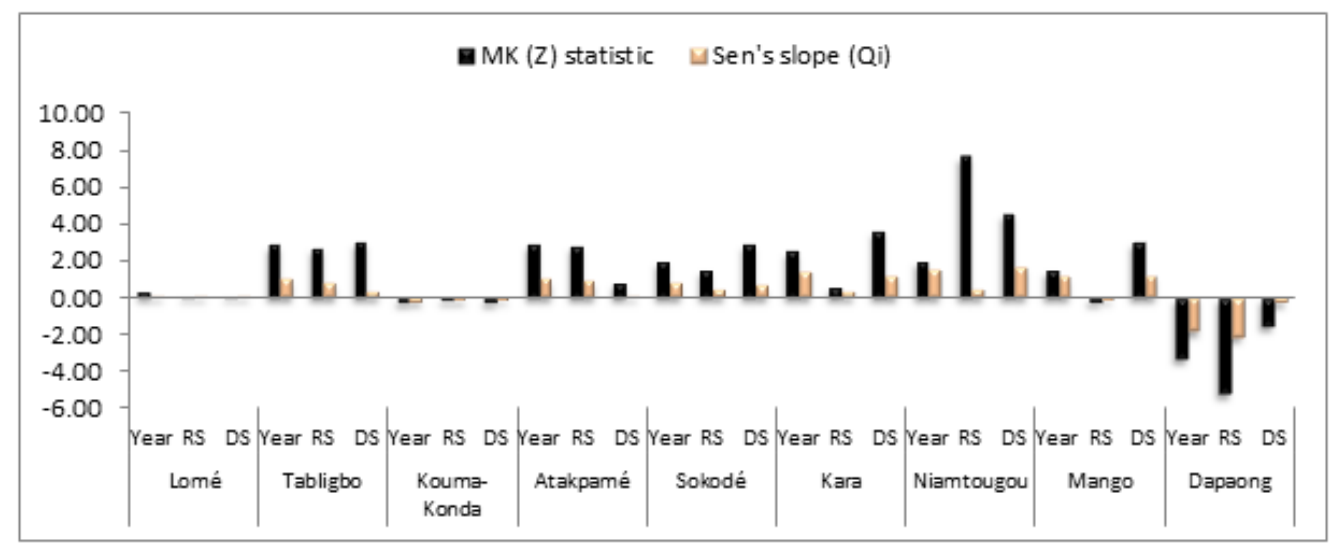

Fig-1: Mann-Kendall standard (Z) statistic and Sen slope magnitude (Qi) for all stations (Evapotranspiration mm/year, rainy and dry seasons)

Source: Authors

2.2. Analysis of evapotranspiration sensitivity to other meteorological variables

The results of the sensitivity analysis by meteorological station are presented in Figure 4, considering the annual and seasonal (wet and dry seasons) time scales. For all stations, whether annual or seasonal, evapotranspiration (ETr) better correlates with minimal temperature (Tmin) and maximal temperature (Tmax). The correlation between ETr and Tmax is significant for all stations at the annual and seasonal scales, with the exception of the Dapaong station in dry seasons. Temperatures (maximal and minimal) are the 
BALAKA Manamboba Mitélama \& YOVO Koffi., Sch J Econ Bus Manag, Apr, 2021; 8(4): 98-109

main variables influencing the trend in ETr at all scales and at all stations followed by relative humidity (maximal and minimal) and insolation. The upward trend of annual evapotranspiration, in both wet and dry seasons at Tabligbo is related to temperature (maximal and minimal), precipitation and maximum relative humidity. At Atakpamé, the increase in annual and rainy season evapotranspiration is related to temperature (maximal and minimal) and relative humidity (maximal and minimal). The upward trend of evapotranspiration in dry seasons at Sokodé is influenced by maximum temperature, minimum relative humidity and insolation.

Table-4: Spearman rank correlation test applied between ETr and other weather variables by weather station.

\begin{tabular}{|c|c|c|c|c|c|c|c|c|c|}
\hline & Lomé & Tabligbo & Kouma-Konda & Atakpamé & Sokodé & Kara & Niamtougou & Mango & Dapaong \\
\hline \multicolumn{10}{|c|}{ Annual } \\
\hline Pr & 0.10 & $-0.25+$ & $0.43 * *$ & -0.03 & $-0.41 * *$ & -0.05 & -0.05 & 0.09 & -0.24 \\
\hline Tmax & $0.38 * *$ & $0.85 * *$ & $0.68 * *$ & $0.68 * *$ & $0.80 * *$ & $0.53 * *$ & $0.86 * *$ & $0.74 * *$ & $0.36 *$ \\
\hline Tmin & $-0.25+$ & $0.51 * *$ & $-0.41 * *$ & $0.67 * *$ & $0.38 * *$ & 0.04 & 0.17 & $0.33^{*}$ & $-0.71 * *$ \\
\hline Hmax & -0.24 & $-0.36+$ & -0.01 & -0.17 & $0.28+$ & -0.06 & 0.11 & -0.11 & 0.05 \\
\hline Hmin & $-0.56^{* *}$ & -0.28 & 0.30 & $-0.46 * *$ & 0.27 & 0.03 & 0.19 & $-0.45^{*}$ & -0.18 \\
\hline $\mathbf{I}$ & $0.41 *$ & & 0.05 & -0.20 & -0.31 & 0.11 & $0.55 * *$ & -0.21 & \\
\hline $\mathbf{W}$ & 0.15 & 0.02 & -0.13 & -0.17 & 0.01 & 0.01 & -0.14 & 0.13 & $-0.42 * *$ \\
\hline \multicolumn{10}{|c|}{ Rainy seasons } \\
\hline Pr & 0.05 & $-0.29+$ & $0.44 * *$ & -0.03 & $-0.35^{*}$ & 0.00 & -0.06 & 0.24 & -0.17 \\
\hline Tmax & $0.37 *$ & $0.88 * *$ & $0.67 * *$ & $0.67 * *$ & $0.76 * *$ & $0.59 * *$ & $0.89 * *$ & $0.75 * *$ & $0.45 * *$ \\
\hline Tmin & -0.23 & $0.58 * *$ & $-0.38 *$ & $0.69 * *$ & $0.46 * *$ & 0.20 & 0.28 & $0.45 * *$ & $-0.60 * *$ \\
\hline Hmax & -0.27 & -0.23 & -0.10 & $-0.37 *$ & $-0.34 *$ & $-0.31+$ & 0.19 & -0.24 & 0.30 \\
\hline Hmin & $-0.64 * *$ & -0.16 & $0.37+$ & $-0.48 * *$ & 0.08 & -0.05 & 0.25 & -0.20 & -0.08 \\
\hline I & 0.25 & & -0.01 & -0.15 & -0.21 & -0.04 & $0.55 * *$ & -0.14 & \\
\hline W & 0.11 & 0.03 & -0.22 & -0.21 & 0.22 & -0.07 & -0.15 & 0.16 & $-0.42 *$ \\
\hline \multicolumn{10}{|c|}{ Dry seasons } \\
\hline Pr & 0.06 & 0.00 & -0.08 & -0.12 & -0.06 & $-0.35^{*}$ & -0.17 & $-0.32 *$ & $-0.31 *$ \\
\hline Tmax & $0.36 *$ & $0.66 * *$ & $0.57 * *$ & $0.47 * *$ & $0.70 * *$ & $0.42 * *$ & $0.65 * *$ & $0.62 * *$ & 0.17 \\
\hline Tmin & $-0.25+$ & $0.30 *$ & $-0.64 * *$ & $0.49 * *$ & $0.27+$ & -0.12 & 0.09 & 0.24 & $-0.69 * *$ \\
\hline Hmax & -0.09 & -0.31 & -0.07 & 0.17 & $0.33+$ & 0.08 & 0.04 & -0.08 & -0.10 \\
\hline Hmin & $-0.36^{*}$ & -0.33 & -0.12 & 0.03 & $0.50 * *$ & 0.03 & 0.06 & $-0.46^{*}$ & -0.23 \\
\hline I & $0.35 *$ & & 0.16 & -0.23 & $-0.36^{*}$ & 0.17 & $0.38 *$ & -0.18 & \\
\hline $\mathbf{W}$ & 0.12 & -0.07 & 0.13 & -0.04 & -0.12 & 0.03 & -0.25 & 0.11 & $-0.34 *$ \\
\hline
\end{tabular}

Significant correlation: ** at 1\%, * at 5\% and + at $10 \%$.

Source: Authors

The upward trend in annual and dry season evapotranspiration is related to maximum temperature at Kara and to maximum temperature and insolation at Niamtougou. At Mango, the upward trend in evapotranspiration in the dry season is influenced by rainfall, maximum temperature and minimum relative humidity. At Dapaong, the downward trend in annual and rainy season evapotranspiration is related to temperature (maximal and minimal) and wind speed.

A similar analysis is made by region. The results of the annual and seasonal correlation analysis are presented in table 5. For all regions, whether at the annual or seasonal scale, ETr has better correlation with temperature (Tmax and Tmin). The correlation between Etr and temperature is significant in all regions. At the regional scale, the trend in evapotranspiration is mainly influenced by Tmax and Tmin, followed by insolation and relative humidity (maximal and minimal).

This study, like those of $\mathrm{Xu}$ et al. [44] and Ohmura et Wild [46] indicates that the trend in evapotranspiration is not solely dependent on temperature. Indeed, like most studies that have analysed the spatio-temporal variability of evapotranspiration in different regions, this study links it mainly to increasing temperature [9] insolation and relative humidity. The results obtained corroborate those of the study carried out by Sonali et Kumar [5], which revealed a high correlation between potential evapotranspiration and maximum temperature at both monthly and seasonal scales. Tabari et al. [28] linked the positive trend in annual evapotranspiration in the western half of Iran mainly to temperature increases. 
BALAKA Manamboba Mitélama \& YOVO Koffi., Sch J Econ Bus Manag, Apr, 2021; 8(4): 98-109

Table-5: Spearman rank correlation test applied between ETr and other weather variables by region.

\begin{tabular}{|c|c|c|c|c|c|}
\hline \multicolumn{7}{|c|}{} & Maritime & Plateau & Centrale & Kara & Dapaong \\
\hline Pr & -0.07 & $0.27+$ & $-0.41^{* *}$ & -0.03 & -0.09 \\
\hline Tmax & $0.56^{* *}$ & 0.03 & $0.80^{* *}$ & $0.78^{* *}$ & 0.13 \\
\hline Tmin & 0.11 & $-0.54^{* *}$ & $0.38^{* *}$ & $0.33^{*}$ & $-0.49^{* *}$ \\
\hline Hmax & $-0.30+$ & $-0.32+$ & $0.28+$ & -0.12 & 0.19 \\
\hline Hmin & $-0.40^{*}$ & $-0.65^{* *}$ & 0.27 & -0.02 & 0.02 \\
\hline I & $0.34^{*}$ & 0.14 & -0.31 & $0.53^{* *}$ & $0.49^{* *}$ \\
\hline W & 0.1525 & 0.1839 & 0.009 & -0.0992 & -0.1285 \\
\hline \multicolumn{7}{|c|}{ Rainy seasons } \\
\hline Pr & -0.08 & $0.27+$ & $-0.35^{*}$ & 0.01 & -0.01 \\
\hline Tmax & $0.59^{* *}$ & -0.01 & $0.76^{* *}$ & $0.80^{* *}$ & 0.17 \\
\hline Tmin & 0.17 & $-0.55^{* *}$ & $0.46^{* *}$ & $0.38^{*}$ & $-0.41^{* *}$ \\
\hline Hmax & $-0.36^{*}$ & $-0.47^{* *}$ & $-0.34^{*}$ & $-0.34^{*}$ & $0.35+$ \\
\hline Hmin & $-0.37 *$ & $-0.64^{* *}$ & 0.08 & 0.07 & 0.15 \\
\hline I & $0.34^{*}$ & 0.12 & -0.21 & $0.52^{* *}$ & $0.34^{*}$ \\
\hline W & 0.1598 & 0.1488 & 0.2249 & -0.1083 & -0.1271 \\
\hline \multicolumn{7}{|c|}{ Dry seasons } \\
\hline Pr & 0.03 & 0.09 & -0.06 & $-0.30+$ & $-0.33^{*}$ \\
\hline Tmax & $0.51^{* *}$ & 0.14 & $0.70^{* *}$ & $0.63^{* *}$ & 0.09 \\
\hline Tmin & 0.02 & $-0.59^{* *}$ & $0.27+$ & 0.22 & $-0.46^{* *}$ \\
\hline Hmax & -0.17 & -0.09 & $0.33+$ & -0.01 & 0.01 \\
\hline Hmin & $-0.33^{*}$ & -0.26 & $0.50^{* *}$ & -0.06 & -0.07 \\
\hline I & 0.08 & 0.12 & $-0.36^{*}$ & $0.43^{* *}$ & $0.51^{* *}$ \\
\hline W & 0.0932 & -0.0095 & -0.1209 & -0.1947 & 0.0014 \\
\hline
\end{tabular}

Significant correlation: **at 1\%, * at 5\% and +at $10 \%$.

Source: Authors

In addition, the results are similar to those of Zhang et al. [48] who found that the main causes of the trend in reference evapotranspiration in China were the decrease in solar radiation in humid regions and the decrease in wind speed in arid and semi-arid regions. According to Yin et al. [8], the decreasing trend in potential evapotranspiration observed in China is primarily attributed to wind speed, in particular because of its strong downward trend. Espadafor et al. [27] linked the significant increase in potential evapotranspiration in southern Spain to an increase in air temperature, solar radiation and a decrease in relative humidity. Also, decrease in potential evapotranspiration has been attributed mainly to decrease in sunshine duration [31, 43, 66, 67], wind speed [41, 42, 45, 68, 69] and relative humidity [39].

\section{CONCLUSION}

In this study, the variability and trend in evapotranspiration and its sensitivity to rainfall, temperature, relative humidity, insolation and wind speed at ten meteorological stations in Togo were analyzed at national, regional and seasonal scales. Climate change strongly influences meteorological variables including evapotranspiration. It is more affected because of its dependence on climate change and other meteorological variables. Assessing the trend in evapotranspiration and its sensitivity to other weather variables is the objective of this study. The basic statistical parameters used are the non-parametric methods of Mann-Kendall (MK) and Sen [56] and the Spearman rank correlation test. The results revealed a high spatio-temporal variability in evapotranspiration. A general upward trend in evapotranspiration was detected at monthly, annual and seasonal scales. A higher correlation between evapotranspiration and temperature (maximal and minimal) is noted at the national, regional and seasonal scales. There is also a correlation between evapotranspiration and relative humidity (maximal and minimal) as well as precipitation and insolation.

Increased evapotranspiration influences agricultural production and ecosystems negatively. Indeed, evapotranspiration is an important variable for hydrology and agriculture. This study has the merit of analyzing, at the local level, the spatio-temporal variation of evapotranspiration and its sensitivity to other meteorological variables.

\section{REFERENCE}

1. IPCC. The Scientific Basis. Contribution of Working Group I to the Third Assessment Report of the Intergovernmental Panel on Climate Change. Cambridge University Press: Cambridge, United Kingdom. 2001;881. 
2. Coulibaly N, Coulibaly TJH, Mpakama Z, Savané I. The impact of climate change on water resource availability in a trans-boundary basin in West Africa: The case of Sassandra. Hydrology. 2018;5(1):12.

3. Valipour M, Sefidkouhi MAG. Temporal analysis of reference evapotranspiration to detect variation factors. International Journal of Global Warming. 2018;14(3):385- 401.

4. Ali RO, Abubaker SR. Trend analysis using mannkendall, sen's slope estimator test and innovative trend analysis method in Yangtze river basin, china. International Journal of Engineering \&Technology. 2019;8(2):110-9.

5. Sonali P, Kumar DN. Spatio-temporal variability of temperature and potential evapotranspiration over India. Journal of Water and Climate change. 2016;7(4):810- 22.

6. Mansour M, Hachicha M, Mougou A. Trend analysis of potential evapotranspiration case of Chott-Meriem Region (The Sahel of Tunisia). International Journal of Agriculture Innovations and Research. 2017;5(5):703-8.

7. Wang W, Xing W, Shao Q, Yu Z, Peng S, Yang T. Changes in reference evapotranspiration across the Tibetan Plateau: Observations and future projections based on statistical downscaling. Journal of Geophysical Research: Atmospheres. 2013;118(10):4049- 68.

8. Yin Y, Wu S, Chen G, Dai E. Attribution analyses of potential evapotranspiration changes in China since the 1960s. Theoretical and Applied Climatology. 2010;101(1 - 2):19- 28.

9. Obada E, Alamou EA, Chabi A, Zandagba J, Afouda A. Trends and Changes in Recent and Future Penman-Monteith Potential Evapotranspiration in Benin (West Africa). Hydrology. 2017;4(3):38.

10. Bates B, Kundzewicz Z, Wu S. Climate change and water. Intergovernmental Panel on Climate Change Secretariat; 2008.

11. Liu X, Luo Y, Zhang D, Zhang M, Liu C. Recent changes in pan-evaporation dynamics in China. Geophysical Research Letters. 2011;38(13).

12. Van Der Velde Y, Lyon SW, Destouni G. Datadriven regionalization of river discharges and emergent land cover-evapotranspiration relationships across Sweden. Journal of Geophysical Research: Atmospheres. 2013;118(6):2576- 87.

13. Yong-fang Z, Jun-li D, De-xin G, Chang-jie J, Anzhi W, Jia-bing W. Spatiotemporal changes of potential evapotranspiration in Songnen Plain of Northeast China. Yingyong Shengtai Xuebao. 2011;22(7).

14. Zhang X, Chen S, Sun H, Shao L, Wang Y. Changes in evapotranspiration over irrigated winter wheat and maize in North China Plain over three decades. Agricultural Water Management. 2011;98(6):1097- 104.
15. Hobbins MT, Ramírez JA, Brown TC. Trends in pan evaporation and actual evapotranspiration across the conterminous U.S.: Paradoxical or complementary? Geophys Res Lett. juill 2004;31(13):n/a-n/a.

16. Jhajharia D, Pandey PK, Dabral PP, Kumar R, Choudhary R. Variability in Temperature and Potential Evapotranspiration over West Siang in Arunachal Pradesh, India. Jour Ind Geol Cong. 2015;7(2):37- 43.

17. Sun S, Chen H, Wang G, Li J, Mu M, Yan G. Shift in potential evapotranspiration and its implications for dryness/wetness over Southwest China. Journal of Geophysical Research: Atmospheres. 2016;121(16):9342- 55.

18. Rim C-S. The effects of urbanization, geographical and topographical conditions on reference evapotranspiration. Climatic change. 2009;97(3-4):483.

19. Chaouche K, Neppel L, Dieulin C, Pujol N, Ladouche B, Martin E. Analyses of precipitation, temperature and evapotranspiration in a French Mediterranean region in the context of climate change. Comptes Rendus Geoscience. 2010;342(3):234- 43.

20. El-Nesr. Analysis of Evapotranspiration Variability and Trends in the Arabian Peninsula. American Journal of Environmental Sciences. 1 juin 2010;6(6):535- 47.

21. Huo Z, Dai X, Feng S, Kang S, Huang G. Effect of climate change on reference evapotranspiration and aridity index in arid region of China. Journal of Hydrology. juin 2013;492:24- 34.

22. Kousari MR, Zarch MAA, Ahani H, Hakimelahi H. A survey of temporal and spatial reference crop evapotranspiration trends in Iran from 1960 to 2005. Climatic change. 2013;120(1 - 2):277- 98.

23. Liu M, Tian H, Yang Q, Yang J, Song X, Lohrenz $\mathrm{SE}$, et al. Long-term trends in evapotranspiration and runoff over the drainage basins of the Gulf of Mexico during 1901-2008. Water Resources Research. 2013;49(4):1988- 2012.

24. Talaee PH, Some'e BS, Ardakani SS. Time trend and change point of reference evapotranspiration over Iran. Theoretical and applied climatology. 2014;116(3-4):639- 47.

25. Burt TP, Shahgedanova M. An historical record of evaporation losses since 1815 calculated using long-term observations from the Radcliffe Meteorological Station, Oxford, England. Journal of hydrology. 1998;205(1- 2):101- 11.

26. Kay AL, Bell VA, Blyth EM, Crooks SM, Davies HN, Reynard NS. A hydrological perspective on evaporation: historical trends and future projections in Britain. Journal of Water and Climate Change. 2013;4(3):193 - 208.

27. Espadafor M, Lorite IJ, Gavilán P, Berengena J. An analysis of the tendency of reference evapotranspiration estimates and other climate variables during the last 45 years in Southern 
Spain. Agricultural Water Management. avr 2011;98(6):1045- 61.

28. Tabari H, Marofi S, Aeini A, Talaee PH, Mohammadi K. Trend analysis of reference evapotranspiration in the western half of Iran. Agricultural and forest meteorology. 2011;151(2):128- 36 .

29. Onyutha C. Statistical analyses of potential evapotranspiration changes over the period 19302012 in the Nile River riparian countries. Agricultural and forest meteorology. 2016;226:80- 95.

30. Ibrahim B. Caractérisation des saisons de pluies au Burkina Faso dans un contexte de changement climatique et évaluation des impacts hydrologiques sur le bassin du Nakanbé [PhD Thesis]. [Paris VI]: Université Pierre et Marie Curie; 2012.

31. Cohen S, Ianetz A, Stanhill G. Evaporative climate changes at bet Dagan, Israel, 1964-1998. Agricultural and Forest Meteorology. 2002;111(2):83- 91.

32. Gao G, Chen D, Xu C, Simelton E. Trend of estimated actual evapotranspiration over China during 1960-2002. Journal of Geophysical Research: Atmospheres. 2007;112(D11).

33. Irmak S, Kabenge I, Skaggs KE, Mutiibwa D. Trend and magnitude of changes in climate variables and reference evapotranspiration over 116-yr period in the Platte River Basin, central Nebraska-USA. Journal of Hydrology. 2012;420:228- 44.

34. Darshana P Ashish, Pandey RP. Analysing trends in reference evapotranspiration and weather variables in the Tons River Basin in Central India. Stoch Environ Res Risk Assess. août 2013;27(6):1407 - 21.

35. Golubev VS, Lawrimore JH, Groisman PY, Speranskaya NA, Zhuravin SA, Menne MJ. Evaporation changes over the contiguous United States and the former USSR: A reassessment. Geophysical Research Letters. 2001;28(13):2665 - 8.

36. Lawrimore JH, Peterson TC. Pan evaporation trends in dry and humid regions of the United States. Journal of Hydrometeorology. 2000;1(6):543- 6.

37. Roderick ML, Farquhar GD. Changes in Australian pan evaporation from 1970 to 2002. International Journal of Climatology: A Journal of the Royal Meteorological Society. 2004;24(9):1077- 90.

38. Roderick ML, Farquhar GD. Changes in New Zealand pan evaporation since the 1970s. International Journal of Climatology: A Journal of the Royal Meteorological Society. 2005;25(15):2031 - 9.

39. Chattopadhyay N, Hulme M. Evaporation and potential evapotranspiration in India under conditions of recent and future climate change. Agricultural and Forest Meteorology. 1997;87(1):55- 73.
40. Moonen AC, Ercoli L, Mariotti M, Masoni A. Climate change in Italy indicated by agrometeorological indices over 122 years. Agricultural and Forest Meteorology. 2002; 111(1):13- 27.

41. Shenbin C, Yunfeng L, Thomas A. Climatic change on the Tibetan Plateau: potential evapotranspiration trends from 1961-2000. Climatic change. 2006;76(3- 4):291 - 319.

42. Zhang Y, Liu C, Tang Y, Yang Y. Trends in pan evaporation and reference and actual evapotranspiration across the Tibetan Plateau. Journal of Geophysical Research: Atmospheres. 2007;112(D12).

43. Liu B, Xu M, Henderson M, Gong W. A spatial analysis of pan evaporation trends in China, 19552000. Journal of Geophysical Research: Atmospheres. 2004;109(D15)

44. Xu C, Gong L, Jiang T, Chen D, Singh VP. Analysis of spatial distribution and temporal trend of reference evapotranspiration and pan evaporation in Changjiang (Yangtze River) catchment. Journal of hydrology. 2006;327(1 - 2):81 - 93.

45. Burn DH, Hesch NM. Trends in evaporation for the Canadian Prairies. Journal of Hydrology. 2007;336(1- 2):61 - 73.

46. Ohmura A, Wild M. Is the hydrological cycle accelerating? Science. 2002;298(5597):1345 - 6.

47. Goyal RK. Sensitivity of evapotranspiration to global warming: a case study of arid zone of Rajasthan (India). Agricultural Water Management. 2004;69(1):1 - 11.

48. Zhang D, Liu X, Hong H. Assessing the effect of climate change on reference evapotranspiration in China. Stochastic environmental research and risk assessment. 2013;27(8):1871- 81.

49. Chattopadhyay S, Edwards DR. Long-term trend analysis of precipitation and air temperature for Kentucky, United States. Climate. 2016;4(1):10.

50. Asfaw A, Simane B, Hassen A, Bantider A. Variability and time series trend analysis of rainfall and temperature in northcentral Ethiopia: A case study in Woleka sub-basin. Weather and Climate Extremes. Mars 2018;19:29- 41.

51. Adewi E, Badameli K, Dubreuil V. Évolution des saisons des pluies potentiellement utiles au Togo de 1950 à 2000. Climatologie. 2010; (Volume 7):89- 107.

52. Maléki BH, Kpérkouma W, Komlan B, Koffi A, Sidéra EK. Analyse de la variabilité temporelle et spatiale des séries climatiques du nord du togo entre 1960 et 2010. European Scientific Journal. 2014;10(11).

53. Aawar T, Khare D, Singh L. Identification of the trend in precipitation and temperature over the Kabul River sub-basin: a case study of Afghanistan. Modeling Earth Systems and Environment. 2019;5(4):1377- 94. 
54. Hare W. Assessment of knowledge on impacts of climate change-contribution to the specification of art. 2 of the UNFCCC: Impacts on ecosystems, food production, water and socio-economic systems. 2003;

55. Meena PK, Khare D, Shukla R, Mishra PK. Long term trend analysis of mega cities in northern India using rainfall data. Indian Journal of Science and Technology. 2015;8(3):247.

56. Sen PK. Estimates of the regression coefficient based on Kendall's tau. Journal of the American statistical association. 1968;63(324):1379- 89.

57. Mann HB. Nonparametric tests against trend. Econometrica: Journal of the Econometric Society. 1945;245- 59.

58. Kendall MG. Rank Correlation Methods, Book Series, Charles Griffin. Oxford University Press, USA, London; 1975.

59. Birsan M-V, Molnar P, Burlando P, Pfaundler M. Streamflow trends in Switzerland. Journal of hydrology. 2005;314(1- 4):312- 29.

60. Theil H. A rank-invariant method of linear and polynomial regression analysis. In: Henri Theil's contributions to economics and econometrics. Springer; 1992. p. 345- 81.

61. Von Storch H. Misuses of statistical analysis in climate research. In: Analysis of climate variability: Applications of Statistical Techniques. Springer. 1999:11- 26.
62. Hamed KH, Rao AR. A modified Mann-Kendall trend test for autocorrelated data. Journal of hydrology. 1998;204(1- 4):182-96.

63. Yue S, Pilon P, Phinney B, Cavadias G. The influence of autocorrelation on the ability to detect trend in hydrological series. Hydrological processes. 2002;16(9):1807- 29.

64. Yue S, Wang C. The Mann-Kendall test modified by effective sample size to detect trend in serially correlated hydrological series. Water resources management. 2004;18(3):201- 18.

65. MERF. Troisième communication nationale sur le changement climatique au Togo. Lomé-Togo. $2015 ; 160$

66. Thomas A. Spatial and temporal characteristics of potential evapotranspiration trends over China. International Journal of Climatology: A Journal of the Royal Meteorological Society. 2000;20(4):381 - 96.

67. Gao G, Chen D, Ren G, Chen Y, Liao Y. Spatial and temporal variations and controlling factors of potential evapotranspiration in China: 1956-2000. Journal of Geographical Sciences. 2006;16(1):3- 12.

68. Rayner DP. Wind run changes: the dominant factor affecting pan evaporation trends in Australia. Journal of Climate. 2007;20(14):3379 - 94.

69. Roderick ML, Rotstayn LD, Farquhar GD, Hobbins MT. On the attribution of changing pan evaporation. Geophysical research letters 2007;34(17). 